\title{
Who is more related to the nature? A study from Indonesia
}

\author{
Dimas Teguh Prasetyo ${ }^{1}$, Ratna Djuwita $^{1^{*}}$, and Amarina Ariyanto ${ }^{1}$ \\ ${ }^{1}$ Faculty of Psychology, Applied Psychology Department, Universitas Indonesia, Depok, Indonesia
}

\begin{abstract}
Previous research had shown that current generation had lower relatedness to nature, but these findings came from studies with mostly western respondents. This study aims to explore-nature relatedness in Indonesian students and to identified what factors are related to their nature relatedness. 363 students from several universities in Indonesia joined the online survey. They were between 17- 43 years old. In our study, we found that Indonesia students were moderately in nature relatedness $(M=85,73$, $\mathrm{SD}=12,137)$. Nature relatedness was not related to age, gender, home town, vehicles used for transportation, and time used for smartphones. The major findings of this study have shown that students who are environmental activist were the most related to nature. To enhance nature relatedness, we suggests that joining environmental activities is a good way to promote nature relatedness.
\end{abstract}

\section{Introduction}

Nature relatedness consists of the feelings and thoughts that individuals towards their relation to nature [1] Nature relatedness was introduced by Nisbet, Zelenski, and Murphy [1], explained that nature relatedness is associated with the affective, cognitive and physical relation between human and the natural world. Nisbet [2] believed that nature relatedness can be assessed as an indicator of whether our innate trait has a connection with nature. Relationships with nature are also transmitted through knowledge, attitudes, beliefs, and behaviors such as the prudent use of natural resources, reducing waste, managing waste and so on [2].

Humans are basically close to nature. Literature research has shown that individuals who are closer to nature are healthier will keep the best of the natural environment. However, humans who damage their natural environment will reciprocate the reduction of health provided by the environment [4]. Enviromental psychology scholars believed that humans have a fundamental and genetically based need to affiliate with nature [4]. Nisbet, Zelensky, and Murphy [1] developed a scale to measure this relatedness between h.uman and nature. Several environmental psychology studies used their Nature Relatedness Scale and these previous studies suggested that there is a correlation between individuals who have direct exposure to nature with pro-environmental concerns and behaviors [2]. It is also

\footnotetext{
* Corresponding author: juwitas@ui.ac.id
} 
found that nature relatedness is associated with happiness [3] emotional intelligence [5] improvement of physical and psychological health [5],[6],[7], and decreased anxiety [8].

Natural environment also has been a learning resource that promotes resilience in youth and positively correlated with their future life opportunities [9]. Some studies shows that individuals are more willing to do physical activity if they are ini a vast (over 7 ha), clean and neat natural environment. Being active in outdoors also has a positive influence on the improvement of psychological well-being and decreased anxiety [6], [10]. Individuals who are more frequent and takes time visiting green space will have lower rates of depression, normal blood pressure and better social relation [14] The lack of exposure to nature leads to a nature-deficit disorder that resulted from increased ADHD symptoms in children, a potential for obesity, impaired learning development and poor health [11]. Literature also found personal factors related to feeling to the nature such as age and sex [12], physical activity [8], problematic of smartphones [13], residence [14], and involvement as a member of environmental community [15] has correlated to nature relatedness. Unfortunately, these studies are done mostly in western world outside of Indonesia context. Therefore, the aim of this study is to explore the nature relatedness of students in Indonesia and to identify what factors were related to nature relatedness.

\section{Method}

Measurement instruments for this study were adopted from prior studies done by Nisbet, Zelenski, and Murphy [1]. 363 undergraduate and postgraduate program students participated in this study. They came from several universities in Indonesia (Jakarta, Depok, Bogor, Bandung, Yogyakarta, Bali, Aceh, Palembang, and Maluku). Data were collected through a convenience sample using online survey method. The confidence level of the study is $95 \%$ with a $1,24 \%$ margin of error, $71,6 \%$ of the participants are female and $29.4 \%$ were male. The respondents' average age was 22,4 years old. Most of them $(71.1 \%)$ are between $17-23$ and about $28,9 \%$ between $24-43$ years old. $65 \%$ of the participants from undergraduate and $35 \%$ from postgraduate program.

For the aim of this research, nature relatedness is defined as individual's feeling related to nature that includes his appreciation and understanding of relationship to all things on earth which measured with NR-Scale [1]. The instrument of this study was validated and adapted to Indonesian language (Bahasa Indonesia). The reliability for dependent variable (nature relatedness) consisting of 19 items was 0.84. 2 items from original NR-Scale was deleted because it was poorly correlated in reliability test ("I take notice of wildlife wherever I am", "Animals, birds, and plants should have fewer rights than humans"). The scale was measured with Likert scale ( $1-6$, from disagree strongly until strongly agree). The data was analyzed with SPSS programme version 24 .

The dependent variables to explore factors correlated with nature relatedness are age, gender, involvement as member environmental community/ environmental activist ("Are you a member of environmental community/ environmental activist?"), home town ("Where do you grew up ?"), vehicles used as transportation ("What kind of vehicle do you use to reach your campus?"), and time used of smartphones ("How long do you spent your time to use smartphones?").

\section{Result}

We found that Indonesia students has moderately nature relatedness $(\mathrm{M}=85,73, \mathrm{SD}=$ 12,13). This study also explores the nature relatedness of Indonesian students according to several factors such as age, gender, involvement in environmental communities, home 
town, vehicles used as transportation, and time used of smartphones. Data of age, gender and community involvement were analysed using independent sample t-test to see the difference between 2 binary responses. Whereas in the data of home town, vehicles used as transportation and time used of smartphones were analyzed using One-way ANOVA to see differences of response which containing more than two categorical items.

Table 1. Independent sample t-test.

\begin{tabular}{|c|c|c|c|}
\hline & $\mathrm{M}$ & SD & Sig \\
\hline $\begin{array}{l}\text { Age } \\
\text { Z Generation } \\
\text { Millenials }\end{array}$ & $\begin{array}{l}83.96 \\
90.08\end{array}$ & $\begin{array}{l}11.99 \\
11.40\end{array}$ & .952 \\
\hline $\begin{array}{l}\text { Gender } \\
\text { Male } \\
\text { Female }\end{array}$ & $\begin{array}{l}86.55 \\
85.40\end{array}$ & $\begin{array}{l}11.39 \\
12.42\end{array}$ & .572 \\
\hline $\begin{array}{c}\text { Environment } \\
\text { community } \\
\text { involvement } \\
\text { Yes } \\
\text { No }\end{array}$ & $\begin{array}{l}87.08 \\
85.35\end{array}$ & $\begin{array}{l}13.78 \\
11.62\end{array}$ & $.014^{*}$ \\
\hline
\end{tabular}

*) level of significance 0.05

Based on the three factors analyzed using independent sample t-test it was found that only involvement in the environmental community had significant differences. The first factor is the age that was divided into two categories ( $1=$ Z-generation (17-23 years), $2=$ millennials (24-43 years). The results have shown that millennials $(M=90.08)$ have higher nature relatedness than Z-generation $(\mathrm{M}=83.96)$, but there is no significant difference in this category $(\mathrm{p}>.05 ; \mathrm{p}=.952)$. The results have shown that male participants had a higher nature relatedness $(M=86.55)$ than women participants $(M=85.40)$, but the difference was not significant $(\mathrm{p}>.05 ; \mathrm{p}=.572)$. Respondents were asked, "Are you an environmental activist/member of an environmental organization movement". The results have shown that there were significant differences between individuals who are environmentalist organization movement $\theta$ members $(\mathrm{p}<.05 ; \mathrm{p}=.014)$. Compared to individuals who are not involved in environmental communities, environmental activist/ members of the environmental community have higher nature relatedness.

Table 2. One Way ANNOVA test.

\begin{tabular}{|l|r|r|c|}
\hline & $\mathrm{M}$ & SD & Sig \\
\hline Home Town & & & .157 \\
$\quad \begin{array}{l}\text { Urban } \\
\text { Sub-Urban }\end{array}$ & 85.29 & 12.63 & \\
$\quad \begin{array}{l}\text { Small City } \\
\text { Rural }\end{array}$ & 80.19 & 11.14 & \\
\hline $\begin{array}{l}\text { Vehicles used as } \\
\text { transportation }\end{array}$ & 88.28 & 12.84 & \\
$\quad \begin{array}{l}\text { Private } \\
\text { Transportation }\end{array}$ & 86.99 & 12.17 & \\
$\begin{array}{l}\text { Public } \\
\text { Transportation }\end{array}$ & 83.69 & 10.73 & \\
$\begin{array}{l}\text { Online } \\
\text { Transportation }\end{array}$ & 85.43 & 16.76 & \\
$\quad$ Walking & 85.76 & 11.48 & \\
$\begin{array}{l}\text { Cycling } \\
\text { Others }\end{array}$ & 85.00 & 11.31 & \\
\hline
\end{tabular}




\begin{tabular}{|l|l|l|l|}
\hline $\begin{array}{l}\text { Time used of } \\
\text { smartphones } \\
\text { O-1 hours }\end{array}$ & 87.57 & 17.03 & \\
1-2 hours & 86.65 & 12.39 & \\
2-3 hours & 86.83 & 13.23 & \\
$\quad \begin{array}{l}\text { More than 3 } \\
\text { hours }\end{array}$ & 85.51 & 11.92 & \\
*) level of significance 0.05 & & \\
\hline
\end{tabular}

Another three factors in this study are home town, vehicles used as transportation and time used for smartphones. Factors of home town were divided into four categories $(1=$ urban, $2=$ sub-urban, $3=$ small city, $4=$ rural). The results have shown that there is no significant difference in this factor $(p>.05 ; p=.157)$. vehicles used as transportation was divided into five categories $(1=$ public transportation, $2=$ online transportation, $3=$ walking, $4=$ cycling, $5=$ others). The results have also shown that there was no significant differences $(\mathrm{p}>.05 ; \mathrm{p}=.615)$. The last, time used of a smartphone was divided into four categories $(1=$ $0-1$ hours, $2=1-2$ hours, $3=2-3$ hours, $4=$ more than 3 hours). The results have shown that there were no significant differences in this category $(\mathrm{p}>.05 ; \mathrm{p}=.886)$.

\section{Discussion}

The exploration of nature relatedness in Indonesia students was investigated using descriptive quantitative methods. The result from this study suggests that students of Indonesia also has moderately in nature relatedness $(\mathrm{M}=85,73, \mathrm{SD}=12,137)$. However participants in this study mostly from urban cities. Indonesia as growing country in line with the increase in population, the rapid development in various regions and the open green land was diminished. As previous study, $\mathrm{Z}$ generation or youth are 17-23 years old judget to have lower nature exposure than other generation [16]. Meanwhile there is no evidence in this study about it. It is possible too that students in Indonesia has lower perspective on environmental issues.

Previous studies outside Indonesia have shown that greater connectedness with nature causes more contact with nature and greater happiness, environmental concerns, and proenvironmental behavior [2]. One of the solutions is developed urban green spaces in urban areas. Urban green spaces made to increase interaction between human and nature by utilizing urban empty space [17]. Some studies have even found that natural exposure artificially through technology can provide nature relatedness [18]. However, direct natural exposure is better than artificial natural exposure to health promotion [7] Previous studies also shown that high levels of natural exposure have been correlated with increased physical activity and have an impact on improving health both physically and psychologically [10]; [6].

The major findings have shown that student who is an environmental activist or has involved a member of environmental community were the most related to the natural ones. These findings support previous studies that environmental activists have higher aspects than non-environmental activists in terms of the perceived importance of environmental issues, responsibilities in preventing health risks, perceptions of health risks, and autonomous motivation levels [19]. Environmental activists can be seen from the characteristics of looking for dwelling close to nature, style of dress, work ethic and political views [15]. The other factors that influence the individual in becoming an environmental activist were age and gender. Although age and gender were factors not significantly correlated in this study, the previous study outside Indonesia has found that Woman and younger were more biocentric [12]. 
In the daily life, environmental activities should be done individually. We can start by using bikes as transportation, composting, sorting waste and so forth. Participatory action starting from self is considered to be closer to the environment [20]. Individuals who participate in environmental activities tend to be interested in choosing options that benefit them [21] such as feeling healthier and avoiding the consequences of environmental problems. However, individuals involved in environmental organization activities have a high tendency to friendship in organizations, environmental values, perceptions of the efficacy of community action, personal feelings about environmental issues, political orientation and activities in other organizations [23]. In addition, social support from fellow activists within the environmental organization was predicted to positively affect individual behavior in the environment [24]. Nevertheless, this study would like to show that direct individual involvement in an activity or a real action in its environment is quite important. Direct experience with nature must have a distinctive characteristic such as the smell of leaves, wind blow, the texture of grass, plants, mud, even animal waste while in nature. Restorative experience is an effort to reflect yourself as part of nature that is not separated.

This study suggests and encourages head of universities in Indonesia to do more concern to the activities or student community related to environmental conservation such as nature lovers, bird lovers clubs, gardening clubs, routine activities of trees planting, studies on environmental issues and so on. Then, the results of this study cannot be justified as causal relationships. The use of self-report can add by a qualitative method to improve the rigorous of this study. The number of respondents in some universities can be increased to improve the representativeness. Future research also needs to pay attention to the important points in this study. Measurement of involvement in environmental organizations or as environmental activists uses only one single question. Going forward, further research can use an environmental activism scale to be able to confirm and see how far an individual has been involved in an environmental organization.

\section{Conclusion}

Based on the research question "who is more related to the nature", the result shows that university students who are active in environmental organizations more related to the nature. Other factors like age, gender, home town, time used of smartphones, residence and vehicles used as transportation does not correlate with their nature relatedness. Students who are active in environmental organization, really know the problems and importance of taking care of our environment. We assume that students who has actual experience in nature, will care more for their nature and really do something to keep their physical surrounding green. That is why these students are more "green" than students who are not involved with environmental issues.

\section{References}

1. E.K. Nisbet, J.M. Zelenski, S.A. Murphy, Environment and Behavior, 41, 715 (2009)

2. E.K.L. Nisbet, A nature relatedness intervention to promote happiness and environmental concern (Doctoral dissertation, Carleton University, 2011)

3. E.K., Nisbet, \& J.M. Zelenski, Psychological Science 22, 1101 (2011)

4. D.D.N. Winter, S. Koger, The Psychology of Environmental Problems: Psychology for Sustainability (Psychology Press, 2014)

5. P.R. Gerofsky, P.R. Gerofsky, The Relationship between Nature Relatedness, Trait Emotional Intelligence and Well-Being (University of Western Ontario, 2016). 
6. F.M. Jansen, D.F. Ettema, C.B.M. Kamphuis, F.H. Pierik, M.J. Dijst, Health \& place 46, 73 (2017)

7. Z. Dömötör, R. Szemerszky, F. Köteles, Journal of health psychology 1359105317699681 (2017)

8. E. Lawton, E. Brymer, P. Clough, A. Denovan, Frontiers in psychology 8, 1058 (2017)

9. J. Barton, R. Bragg, C. Wood, J. Pretty, (Eds.). Green exercise: Linking nature, health and well-being (Routledge, 2016)

10. A. Ellaway, S. Macintyre, X. Bonnefoy, Bmj 331, 611 (2005)

11. R. Louv, Last child in the woods: Saving our children from nature-deficit disorder (Chapel Hill, NC: Algonquin Books, 2008)

12. B.L. McFarlane, Environment and behavior 38, 266 (2006)

13. M. Richardson, Z. Hussain, M.D. Griffiths, Journal of behavioral addictions 1-8 (2018)

14. D.T. Cox, D.F. Shanahan, H.L. Hudson, K.E. Plummer, G.M. Siriwardena, R.A. Fuller,... \& K. Gaston, J. BioScience 67, 147 (2017)

15. D. Horton, The Sociological Review 51, 63 (2003)

16. A. L. Metz, Vistas Online 11, 1 (2017)

17. A. Akpinar, Urban forestry \& urban greening 16, 76 (2016)

18. M.R. Crawford, M.D. Holder, \& B.P. O'Connor, Environment and Behavior 49, 959 (2017)

19. C. Séguin, L.G. Pelletier, J. Hunsley, Environment and Behavior 30, 628 (1998)

20. S. Alisat, M. Riemer, Journal of Environmental Psychology 43, 13 (2015)

21. M. Dresner, The Journal of Environmental Education, 21, 41 (1990)

22. L.C. Manzo, N.D. Weinstein, Environment and Behavior 19, 673 (1987)

23. T.C. Edwards, S. Oskamp, Basic and Applied Social Psychology 13, 217 (1992) 